\title{
Takyif Fiqhi on the Permissibility of Ijarah Mawsufah fi al-Dhimmah: A Critical Analysis ${ }^{1}$
}

\author{
ABU UMAR FARUQ AHMAD*, ABU TALIB MOHAMMAD MONAWER \& LUKMAN AYINDE \\ OLOROGUN $^{2}$
}

\begin{abstract}
Ijarah mawsufah fi al-dhimmah (hereinafter referred to as IMAD), also known as forward ijarah, is an Islamic financial product that involves the sale of an identified asset currently being produced or constructed for a future delivery such as a property, office, factory, and so forth. In the classical fiqh literature, it has been discussed under the general purview of leasing and forward sale contracts. However, in the context of modern Islamic finance practice Islamic banks and financial institutions have upheld its usage as an independent financial instrument. The contemporary scholars claim that except for Hanafi, other key fiqh schools consider IMAD as an Islamic financial product. The study is an attempt to prove that such a claim is merely based on assumption. Besides, it is motivated by lack of holistic study of Hanafi's original reference books. The methodology chosen for this study is content analysis of the relevant published literatures. The study finds that no classical scholars including those of Hanafi school of thought were in disagreement so far over the IMAD to consider it as an independent and standalone Islamic finance product. The study aims at reconciling scholars' different views on the issue of IMAD for its wider acceptance.
\end{abstract}

Keywords: forward lease, ijarah, ijarah mawsufah fi al-dhimmah, IMAD, Islamic finance

The modern Islamic financial institutions (IFIs) have emerged to compete with their conventional counterparts (Doraisamy, Shanmugam \& Raman 2011) with the intention of accommodating and adopting Islamic financial products and services with the underlying principles of Shariah (Ringim 2014). These products include among others musharakah mutanaqisah or diminishing partnership, al-ijarah thumma al-bay' (AITAB) or Islamic hire purchase, bay' bi thaman 'ajil, or better known by its acronyms BBA (sale on deferred payment), istisna 'a (a contract of exchange with deferred delivery) etc. (Ahmed 2014; Al-Salem 2009; Asni \& Sulong 2018; Dieng 2019). All IFIs' products and services have to have approved by the shariah scholars and qualified Islamic jurists (Rafay, Sadiq \& Ajmal 2017). Their authority must also be recognised by the shariah or adopted from earlier scholars' juristic opinions (Ahmed 2014), technically known as takyif fiqhi, also referred to as takhreej fiqhi (Juristic adaptation or jurisprudential characterisation) (Haniyah

\footnotetext{
${ }^{1}$ A version of this article entitled "Dispute over the legality of al-ijarah al-mawsufah fi al-dhimmah: A survey of fiqhi opinions" has been previously published in ISRA International Journal of Islamic Finance 7(1):49-73 in 2015, authored by Abu Talib Mohammad Monawer \& Akhtarzaite Abdul Aziz.

${ }^{2}$ Abu Umar Faruq Ahmad* (corresponding author), Ph.D., associate professor at Islamic Economics Institute, King Abdulaziz University, 21589 JEDDAH, Saudi Arabia, email: aufahmad@gmail.com; Abu Talib Mohammad Monawer, Ph.D. candidate, Department of Fiqh and Usul al-Fiqh, Academy of Islamic Studies, University of Malaya, 50603 KUALA LUMPUR, Malaysia, email: monawer.azhar@gmail.com; Lukman Ayinde Olorogun, Ph.D., lecturer at Faculty of Business, Higher Colleges of Technology, ABU DHABI, United Arab Emirates, email: yinluk2000@yahoo.com.
} 
\& Barakah 2019). The takyif fighi has been used by the Islamic scholars in order to derive an Islamic legal opinion or notion to an emerging matter or fact for which no precedents were found in the context of muamalat (Islamic legal rulings governing commercial transactions) (Bouchelaghem 2015). Often classical Islamic scholars had differences of opinion on such debated issues on the basis of which their permissibility or otherwise were justified. For example, a few most recent Islamic financial contracts such as takaful (Islamic insurance) as an alternative to conventional insurance, or sukuk (asset based Islamic securities) as a substitute of conventional interest based bonds were originally canonised based on takyif fiqhi by likening them to conventional transactions. In this regard, takyif fiqhi involves an Islamic ruling whether or not an issue or product is permissible in compliance with the underlying principles of the shariah (Ahmad \& Hussain 2013).

Despite plethora of financing modes have emerged in Islamic finance industry, ijarah mawsufah fi al-dhimmah (IMAD) which is considered one of the significant modern Islamic finance products (Dewar \& Hussain 2017) seems to remain untapped and has not been discussed widely in the relevant literature, and as such it has received a limited attention to industry players and practitioners. This study is an attempt to fill this gap through justifying the practice of IMAD in strict compliance with the underlying principles of the noble shariah.

The IMAD is a hybrid contract, which is a combination of forward sale and a redeemable leasing agreement. It has been termed by the contemporary scholars as 'forward leasing', which buys out the project (namely a construction one) as a whole at its completion or in portions of the project. In the following section we have attempted to provide key definitions of IMAD provided by our modern time Shariah scholars. As far as the contemporary Shariah scholars are concerned, Abu-Ghuddah (2007) and al-Buti (2007) are considered the pioneers among them who have been successful to pay their peers' attention to IMAD. Subsequently, some other scholars followed them to discuss the issues of IMAD with special reference. Literally known as 'lease described with responsibility', Abu Ghuddah (2007: 73) defined IMAD as:

It is a contract wherein the lessor adheres to render usufruct [i.e., the legal right of using an object] stipulated thoroughly by the qualities of bay' salam [forward sale] - enough to eliminate the potential conflict about the usufruct, whether the subject matter is the benefit of an object such as leasing a stipulated car, or service of a human, such as tailoring and teaching.

Likewise, Shaikh al-Qurahdaghi considers IMAD as a contract where the subject matter is usufruct stipulated in liability in such a way that removes the potential dispute (al-Qurahdaghi 2008:14). However, the contemporary scholar, Nassar puts it in different way. ,According to him IMAD is:

A sale of future usufruct in exchange for immediate cash, first; secondly, a salam contract on usufruct whether the usufruct comes from objects or actions; and third, a rental that entails liability because the fact is that the promised usufruct is attached to the liability of lessor, and is not defined; and finally, it is a rental executed on guaranteed usufruct because the lessor guarantees the usufruct here in all situations and it is attached to his liability (Nassar 2009: 102).

While IMAD is a recent phenomenon as well as a comparatively new mode of Islamic financing transaction, the similar concept has been widely discussed in the Islamic legal heritage particularly in the books of four prominent Sunni schools of thought. Nevertheless, it has generally been discussed under the purview of ijarah mode of transaction, which is commonly known as "providing services and goods temporarily for a wage". Technically, ijarah is defined as: "A lease contract under which a tenant is given the right to use the manfa' ah (usufruct) of an object for a period of time during which the owner retains the ownership of the asset". 
Taqiyyuddin al-Fatuhi, a prominent classical Hambali scholar has mentioned the legitimacy of IMAD while making an oblique reference to contract: "Either the subject matter is a particular existing item or stipulated by specifications" (al-Fatuhi 2000: 3/83). Mansur al-Bahuti, another Hanbali scholar elaborated al-Fatuhi's statement and approved it (al-Bahuti 1051H: 4/28).

This indication is considered to be quite helpful to define the IMAD. The Shafi'i scholar alMinhaji discussed the issue of IMAD more elaborately though, he did not provide a detailed definition. For this contract compared to his predecessors, He only mentioned how IMAD may work while saying: "the mode of ijarah mawsufah fi al-dhimmah is implemented by deferring the usufruct and paying the rental in advance (i.e., forward leasing)" (al-Minhaji 1996: 2/220)

It is evident from the discussions been made in the above sections that classical scholars did not separate IMAD from traditional ijarah; rather, they treated it as an extension of ijarah contract. The contemporary scholars, however, have extended the features of ijarah to accommodate IMAD with the modern wider Islamic commercial contracts in the practice of Islamic banks (IBs) and IFIs. In fact, no arguments were placed by both the classical and contemporary Shariah scholars on the permissibility of IMAD and considering it as an independent Islamic finance instrument. Nevertheless, the contemporary scholars hold different views about the legitimacy of this product and according to them, there are some disagreements among the classical scholars regarding the Islamic legal rulings on the permissibility IMAD. Abu Ghuddah like ,some of his peers such as Kamal and Nassarclaimed that the Hanafi school did not allow the IMAD as a stand-alone Islamic finance contract, and the consequences of which it has not been used as an independent Islamic finance product at the early stage of modern Islamic finance practice. They also claimed that the Shafi'i and Hanbali schools seem to have failed to provide justifications to support their views of the permissibility of IMAD (Abu-Ghuddah 2007: 73-74; Kamal 2007: 328; Nassar 2009: 102-103).

Given the above claims and arguments put aside by our modern-day Shariah scholars, this study seeks to examine the relevant classical literature, particularly the reference books of Islamic jurisprudence of four prominent Sunni schools. It is expected that this will pave the way for proving the fact whether or not the existing literature were thoroughly investigated and wellgrounded on the takyif fiqhi of IMAD, also has any impacts thus far on modern Islamic finance products. To achieve this goal, we have opted to take critical content analysis approach while reviewing the published literatures pertaining to the subject. The plan of the present research is as follows. Following the introduction, the study begins with the discussion of the trends in Islamic legal rulings. It then elucidates the Islamic legal rulings on IMAD from the perspectives of four key Sunni schools of thought. It follows the review of contemporary Scholars' views on IMAD. It then examines the arguments both in favour of, and against the classical legal texts in the literature on IMAD. The study concludes with the summary, conclusion, and suggestions for further research.

\section{Literature Review}

A review of literature reveals that a number of literary works including both classical jurisprudence and discussions of contemporary practices have been examined relating to IMAD. The topics have been examined in the literature are definition of ijarah mawsufah fi al-dhimmah, its legality, parameters, general applications, current products and services using IMAD, banks and countries applied it, and Shariah issues in the current practices.

IMAD was discussed under ijarah as a kind of it by classical scholars namely Malik (179H), al-Tanukhi $(240 \mathrm{H})$, al-Basri $(378 \mathrm{H})$ Ibn-Jallab $(378 \mathrm{H})$ al-Shirazi $(476 \mathrm{H})$, al-Samarqandi $(539 \mathrm{H})$, Nizam (596H), al-Sarakhsi (616H), Ibn Mazah (616H), Ibn Qudamah (620H), al-Nawawi (676H), al-Kalbi (741H), Ibn Muflih al-Maqdisi (763), Ibn Muflih al-Dimashqi (884H), al-Muwaq (897H), alHattab al-Ra'iyni (954H), Ibn Nujaym (970H), al-Minhaji (1051H), al-Bujayrami (1221H) and 
al-Rafi'i (1323H). As no specific attention was paid to IMAD, they did not provide any definition of it.

However, IMAD has recently drawn special attention of the contemporary scholars. Abu Ghuddah (2007), al-QurahDaghi (2008) and Ahmad Nassar (2009) have mentioned some connotations to define IMAD however none of them is concrete. The definition given by Monawer and Aziz (2012: 101) is deemed concrete. They defined IMAD as: "transferring ownership of usufruct stipulated in the liability in exchange for a counter- value with conditions".

Abu Ghuddah, Hammad (2007), Nassar discussed the legality of IMAD and mentioned disagreement of the four Sunni schools of Islamic legal thought on it whereas other scholars namely Monzer Qahaf (2010), al-Suwaylim (2010), Mirah (2012) and al-Shubayli (2012) mentioned consensus about it. Al-Buti (2007), Abu-Ghuddah (2007), al-Qurahdaghi (2008), Nassar (2009b), and al-Dīrshawi (2017) discussed the parameters of IMAD. According to them the parameters of IMAD are a combination of rules of ijarah and salam as it contains the characteristics of both. While Abu Ghuddah (2007) Nassar (2007), Faddad (2009) and alSuwaylim (2010) generally discussed the contemporary applications of IMAD, other scholars discussed its application in different banking products and financial services.

For example, Alrfoa (2004) studied the role of forward ijarah principle described in the financing of the benefit of university education in Islamic banks. Mirah (2012), al-Shubayli (2012), Ghafoor, Saba, and Kouser (2018), Qahaf and al-Jamal (2013), and Jalil and Rahman (2012) applied IMAD in Sukuk. Razak, Abu Samah, and Abdul-Wahab (2016), Asni and Sulong (2018) and Mikail and Rani (2016) discussed the use of IMAD in MMP for Home financing in Malaysia. While Smolo and Hassan (2011) discussed the potentials of the most common scheme for Islamic home financing MM (musharakah mutanaqisah); Aswer, Jalil, and Muhamed (2019) analysed it together with another common scheme for Islamic home financing i.e. BBA (Bay'Bithaman Ajil) including their Shariah issues and proposed a new mode of house financing named as "Adapted Mudarabah Model (AMM)" which they claimed as to be Shariah compliant. Felix and Abubakar (2019) and Mohamad, Salah, Mokhtar, Alwi, and Faigah (2015) applied IMAD in a model for infrastructure Project Financing in Indonesia which is a combination of musharakah-istishna'-IMAD. Muneeza, Mustapha, Badeeu, and Nafiz (2019) proposed IMAD as an Islamic financing instrument to deal with the financial and infrastructural discrepancy in developing Islamic tourism which they considered as viable in Maldives.

Some pieces of research also studied the determinants of IMAD, the problems and challenges of its application, and legal formula and theoretical framework to resolve the problems and overcome the challenges. For example, Alzghadani (2014) identified the most important determinants of forward ijarah financing to the benefit of treatment by highlighting the practical aspect of the procedure, and the factors that influence the financing process. Sana and Malahim (2018) explored the determinants of forward ijarah (religious, legal, administrative and financial determinants) and their impact on financing the benefits of travel and transportation in the Jordanian Islamic Banks. Mutairi (2011) study aimed at explaining the reality of the use of forward ijarah in the loan as a financing tool in the Kingdom of Saudi Arabia. Amer and Radenarmad (2012) investigated the problems and challenges of applying the forward ijarah formula in Islamic banks. Hassan, Muneeza, and Yousoff (2012) identified a legal formula for applying the financing of the benefits described in order to avoid the legal problems of those services in the Islamic financial institutions. Abu Moenes (2013) formulated a model for the financing of benefit services that allowed the customers of Islamic banks to obtain individual financing for the purpose of spending on their own affairs, including the costs of medicine, education, transport, travel, travel tickets, etc.

However, the dispute is observed among the contemporary scholars in approaching the classical literature whether the classical scholars reached a consensus on the legality of IMAD or not. Thus, it remained as a legal dilemma for the followers of different schools of Islamic legal thought (madhahib). The present study aims to fill this gap. 


\section{Trends in Islamic Legal Rulings}

The early legal writings of Muslim scholars have their glorious history, Islamic culture, and civilization. Although they have gained much popularity throughout the era of the four Sunni Islamic schools of thought, during Prophet's lifetime and in the time of his noble companions they were involved to resort to giving legal rulings on limited occasions (Kayadibi 2007).An example s sending two of his companions to Kufah he 'legal verdict issued by them is while the Prophet of such demanded that they would not need to perform 'Asr prayer until their arrival at the city of Kufah. One of the companions interpreted this Prophetic instruction based on his own understanding, and as such thought the Prophet meant by it to observe the prayer upon their arrival at Kufah, while others understood it to perform 'Asr at any point in time on their way to Kufah even before their arrival. Upon their arrival in Kufah they reported their different understandings to the Prophet for which he ruled that both legal decisions the way they understood, were correct (alBukhari 1987: 1/904). In light of this Prophetic tradition, some classical Muslim scholars including Abu Hanifah have an and the Sunnah to resolve'used their grounded knowledge in the Qur the issues regarding which no direct Islamic legal rulings were found during his time in canonical texts (Hallaq 1996; Masud, Messick \& Powers 1996). Nevertheless, a layman is not qualified to issue any such rulings. There are some criteria based on which one may be eligible for issuing legal rulings on any issue that might warrant such an action. These include fulfilling some conditions, the key of them are; (a) The issuing person must be a Muslim, (b) Should be matured i.e., to reach the age of puberty, (c) Must be well versed with the knowledge of the Qur'an together with recitation and explanation, and; (d) Must be qualified with the sciences of Prophetic traditions as well as memorizing them up to the required numbers (Khan \& Ramadan 2011; Salhani 2011).

The contemporary Shariah scholars followed the same methodology of traditional Muslim scholars to derive the legal rulings. Shaykh Mahmud Shaltut, Shaykh Mustafa al-Zarqa, Shaykh Ali Khafif, Shaykh Muhammad Abu Zahrah, Shaykh Muhammad Faraj al-Sanhuri, Shaykh Abdul Wahhab Khallaf, Shaykh Muhammad al-Zafzaf, Dr. Muhammad Sallam Madkur, Dr. Abdul Karim Zaydan are prominent among them (al-Zuhayli 2011). The present-day scholars of modern Islamic finance also employ the same methodology to arrive at legal rulings in the context of Islamic finance practice. Through employing relentless efforts these scholars have been successful to formulate numerous legal rulings on nearly all modern Islamic financial products and instruments. Notably among these scholars are Abu Ghuddah, al--Qurahdaghi, alButi, Usmani, Qutb, Nassar, al-Mirah. Suwaylim, -Syubayli, Qahaf, al-As was mentioned at the outset, they have al transactions which include the justified the need for many modern Islamic financial modes of and evidences to support the practice of IMAD carried out by the IBs and IFIs. There was near consensus among the contemporary Muslim scholars on the authority of IMAD as well as its practice in compliance with principles of Shariah.

\section{Islamic Legal Rulings on IMAD}

As has been stated earlier in this study, the history of Islamic legal rulings is as old as the fundamental sources of Islamic Shariah, in the same way IMAD has attracted attentions of both classical and contemporary Islamic scholars as an acceptable Islamic finance product. This is why the adequate literature is available in both medieval and renaissance scholarship on issues surrounding IMAD. In this section, we have attempted to discuss chronologically the relevant legal rulings that are available and comprise of the views of classical Islamic scholars in general, and the four prominent Sunni schools of thought (i.e., Hanafis, Malikis, Shafi'is and Hanbalis) in particular, followed by the concepts held by the contemporary scholars. 


\section{Hanafi Scholar's Views on IMAD}

Generally, Hanafi scholars have discussed IMAD under the general purview of 'ijarah contract. More precisely, they treated it as a subset of 'ijarah which is legally allowed by all jurists with consensus. The Hanafi scholars hold two views so far on IMAD, one such is held by al-Sarakhsi $(616 \mathrm{H})$, who stated:

There are two opinions (i.e., those who argued in favour of considering usufruct as an asset, and those who argued against it) in the same school regarding whether or not the usufruct can be termed as an asset (al-Sarakhsi 2009:15/137).

Popular among those who argued in favour of usufruct as an asset was Ibn Mazah $(616 \mathrm{H})$ on one hand (Ibn-Mazah 2004: 4/11) while another view is held by Ibn Nujaym $(970 \mathrm{H})$ who argued against the opinion that considers the usufruct as an asset (Ibn-Nujaym n.d. 2/217). Notwithstanding the fact that a number of Hanafi scholars such as al-Samarqandi (1984: 2/361), Ibn-Mazah (2004: 7/509), Nizam (596H/2000: 4/522) and al-Rafi'i (1323H: 1/719) were unanimous on the authority of IMAD, the same view is upheld in the codification of Majallat alAhkam al-'Adliyyah (Ahmad Jawdat Basha 1302H, Maddah 540: 585) and Murshid al-Hayran (Basha 1891, Maddah 598: 152)

\section{Maliki Scholars' Views on IMAD}

The Maliki scholars like their Hanafi peers were unanimous on the permissibility of IMAD virtually terming both properties and services as objects. Maliki scholars including Imam Malik (179H), al-Kalbi $(693-741 \mathrm{H})$, al-Muwaq (897H) and al-Basri $(378 \mathrm{H})$ among others were found to have agreed on the authority of IMAD. Specifically, in his famous treaties alMudawwanah al-Kubra, al-Tanukhi reported that Imam Malik have approved the use of IMAD in regard to services, stating that payments for services can be delayed to any future date (al-Tanukhi 240H: 3/448).

Furthermore, Al-Kalbi $(693-741 \mathrm{H})$ in his book al-Qawanin al-Fiqhiyyah is reported to have said that hiring boats and animals (dabbah) for riding are two types of leases (specific lease and lease in liability) where the rental payments can be delayed to a specific future period (i.e., IMAD) (al-Kalbi 1425H: 182), al-Ra'iyni (2003: 7/500-502) and Ibn Jallab (378H: 2/184) juncture to state also hold the same opinion. Hence it suffices at this that generally, IMAD is an overwhelmedly favourable tool of financing accordding to Maliki School of thought. For example, one of his statement assert: "I will hire an animal or a boat from you" was ruled as a permissible contract whether the payment against the service on the spot or on a later time in both two types of leases as stated above (al-Kalbi 1425H: 182). This was one of the opinions held by Hanafi scholars as well regarding the permissibility of IMAD while terming it as salam of usufruct.

\section{Shafi'i Scholars' Views on IMAD}

The Shafi'i scholars have shared the same view as those of of Hanafis and Malikis. To sum up, the prominent Shafii scholar al-Minhaji (1051H) in his bookJawahir al'Uqud wa Mu'inul Qudat wa alMuwaqqi'in wa al-Shuhud mentioned two types of 'ijarah under the topic 'the essentials of contracts and conditions' (al-Minhaji 1996: 1/360):

1. Ijarah of tangible assets, such as rental of apartments, animals or vehicles (for the use of private or commercial purposes), or engaging the services of unspecified persons only by stating the labour which is the subject matter of the contract (i.e., without specifying any person's name who will engage in giving his labour by way of sewing or building for instance). 
2. Ijarah on an assigned liability (as is the case with IMAD) such as rental of a car of certain specifications or guaranteeing someone on the performance of a service like sewing or construction.

Meanwhile, the scholar al-Shirazi $(476 \mathrm{H})$ in his book al-Muhazzab shared the same view (al-Shirazi 1995: 2/224). In the context of the expression made byal-Minhaji, if a person says, "I have employed you to carry out such and such task," the question may arise whether it means "ijarah mu'ayyanah' or a particular lease, or the commissioning of a liability. To answer to this, two opinions were found on such statement. The more obvious of these two is the first opinion which is forward 'ijarah (i.e., IMAD) (al-Minhaji 1996: 1/360). It can be considered as a specific lease because the lease has expressly stated the worker who is expected to execute such an instruction others such as al-Bujayrami (1996: 3/565) in his Tuhfat al-Habib and Imam al-Nawawi (2003: 4/248) in his Rawdat al-Talibin were found to have the popular views in Shafi i school.

\section{Hanbali Scholars' Views on IMAD}

Hanbali scholars did not have the different view from that is held by other Sunni schools with regard to the authority of IMAD as an Islamic financing tool. Notably among the Hanbali scholars is Ibn Muflih (763H) who classified 'ijarah in his book al-Furu' into three types (al-Maqdisi 2003: 4/440-441):

1. 'Ijarah of a physical or intangible asset which is similar to an object of sale. This is revocable if its future usufruct is impaired at the commencement (of the contract), or while part of the period remains.

2. Ijarah in liability (where the rental payment is postponed to a future date) to provide a generic item meeting certain specification. In this regard, the stipulation of the specifications of bay' salam must be fulfilled, and in case, should it be usurped or destroyed, or a defect appeared in it, its substitute would be mandatory. However, if it becomes impossible to replace it, the lessee has the right to nullify the contract. It will dissolve by default with the passage of (the appointed) time if its validity period is fixed.

3. A forward contract for a designated benefit, like rendering tailoring service, for which payment for service is delayed until the cloth is sewed i.e., the liability is undertaken. Thus, such a liability must be precisely determined to eliminate potential conflict.

Ibn Qudamah (541-620H) also in both of his treaties al-Kafi and al-Mughni classified 'ijarah into three types: (1) 'Ijarah of a particular object, such as houses and properties; (2) 'Ijarah of an object stipulated in liability (i.e., IMAD) such as a camel for riding; and (3) 'Ijarah contract on an action stipulated in liability (which also falls under the category of IMAD), such as tailoring cloths and carrying goods. He compared legality of these three types of 'ijarah with three types of bay' (Ibn Qudamah 1997a: 3/385-386; Ibn Qudamah 1997b: 8/11).

\section{Contemporary Shariah Scholars' Opinions on IMAD}

The modern-day Shariah scholars like their traditional peers have contrived legal rulings on the modern Islamic finance products and instruments in IBs and IFIs. Eminent among those are alButi (2007), Abu Ghuddah (2007), aland ,(2012) Shubayli-al ,(2007) Kamal, (2008) Qurahdaghiwho were supportive of the validity of IMAD alo (2012) Mirahng the line of the classical Shariah scholars. However, they simply differ in their own interpretations and commentaries on the 
relevant texts of the sources of the Shariah in expressing their views as to whether or not the classical Muslim jurists' approval of IMAD is unanimous in nature. Some of these modern scholars asserted that there have been disagreements among the classical fuqaha on the authority of IMAD. However, others tend to claim that the classical fuqaha have unanimously agreed on the legitimacy of IMAD. In the following section we have attempted to make a thorough discussion on their views along with the arguments they put forward in this regard.

\section{Arguments Against the Permissibility of IMAD in Classical Reference Books}

Earlier Scholar's works such as those of Kamal (2007) and Abu Ghuddah (2007) contain a thorough discussion about IMAD which refers to the classical scholar's views on it's authority as a mode of Islamic finance. One such expression states that there were different opinions held by the classical Shariah scholars regarding the acceptability of IMAD as a mode of financing. They specifically claimed that Hanafi scholars unanimously disapproved the use of IMAD as an independent financing tool. Kamal's (2007) following observations are worthy of mention in this regard:

The fuqaha' differed in authority of ijarah mawsufah fi al-dhimmah (lease described with responsibility). The majority Muslim jurists including Malikis, Shafi' is, and Hanbalis attached to the view of its permissibility, whereas the Hanafi scholars stick to the opinion of its stand-alone impermissibility. Perhaps the reason lies with this latter view of impermissibility is that, to them, particularisation of leased items is one of the conditions for the ijarah contract to be valid. Given that, it can be concluded that any contract on the usufruct stipulate in liability which does not attach to any particular object is not allowed. which states:

In order to prove this view, Kamal refers to clause 449 of Majallat al-Ahkam al-'Adliyyah

Particularisation of leased item is required. Therefore, leasing one of the two shops for example, is not allowed unless one of them is particularised or specified" (Basha 1302H: 75).

In addition, the clause 580 of Murshid al-Hayran also mentions: "Consent of both contracting parties and knowledge of usufruct are made as conditions for the legality of "ijarah" (Basha 1891: 146). Besides, a fundamental principle in Hanafi School in this regard is also of paramount importance which states: "Usufruct is not considered as a valuable asset" (al-Sarakhsi 2009: 15/137).

Based on these textual evidences, Kamal concludes that Hanafi scholars do not allow the use of IMAD as an independent financial mode (Kamal 2007: 328). Similarly Nassar (2009) cited disagreement found among the four classical school of Islamic jurisprudence on the validity of IMAD and attributed the view of illegality to the Hanafi School. With regard to this, Nassar (2009) says:

The fuqaha have different views regarding the legality of IMAD. Hanafi scholars adhere to the illegitimacy of leasing usufruct of objects which are stipulated in liability and they require the leasing object to be particularized, whereas the majority of the fuqaha, comprising of Malaikis, Shafiis and Hanbalis adhere to the permissibility of leasing object stipulated in liability and they consider it the similar type of bay' salam in usufruct (Nassar 2009: 102-103). 


\section{Analysis of the Disapproval of IMAD's Permissibility}

Contrary to the contemporary scholars' views which hold that the classical texts contained disagreements on the authority of IMAD revealed the opposite results. Kamal (2007) who stated that majority of Maliki, Shafiie and Hanbali jurists' permissibility of IMAD is found to be correct. However, Kamal did not provide other scholars' minority views from within the same schools. Perhaps, no minority view was found, nor was found any majority view that can be justified by the researcher's findings. In fact, the level at which they approved IMAD is undisputed. Particularly, all the scholars unanimously agreed on the notion that delay in payment for service rendered or to be rendered in future time, is permissible. Although scholars have expressed their views under the discussion of the topic of 'general 'ijarah', nonetheless it is obvious that IMAD had unequivocal support from all classical scholars as it is evident from the above-mentioned discussions on opinions of three schools of thought about the issue.

Furthermore, Kamal claimed consensus among the Hanafi scholars on the impermissibility of IMAD as mode of Islamic finance. On the contrary, the researcher's investigations found that there were agreements among the Shariah scholars on the permissibility of the use of IMAD. Nevertheless, scholars also are of different views whether or not it is permissible to defer the payment in an IMAD contract. The first opinion held by al-Kasani $(587 \mathrm{H})$ states that delay in payment in leasing contract is permissible. Among others al-Ramalli $(1004 \mathrm{H})$ views that deferred payment is not acceptable in IMAD. Likewise, Ibn Jallab $(378 \mathrm{H})$ of Maliki school holds the same opinion. It is worthy of mention here for the clarity that the scope of our present study is limited one way or the other, and as such it did not discuss whether immediate or deferred payment does really matter. In order to justify his stance, Kamal quoted from two additional books excerpting from Majallat al-Ahkam al-'Adliyyah, which is beyond the point of discourse. It states: "Particularization of leased item is required and therefore, leasing one of the two shops is not allowed unless one of them is specified".

For the sake of argument, the evidence is mentioned above is in fact for 'ijarah on two objects. In the Majallat al-Ahkam al-'Adliyyah $(1302 \mathrm{H})$ it is referred that the subject matter of the contract of leasing must be specified. Consequently, if one of the two shops is rented out, without the particular shop in question being specified, and the lessee is being given an option as to which one he will take possession of, such a contract is considered null and void. Here, all that is evident from the text is that the event of giving options takes place after the contract is done. However, these texts are subject to further scrutiny and explanation, and the scope for its rejection remained valid. It is obvious that such clause states that Hanafi School disallows making one of two objects usufruct without any specification or distinction is made between the case of usufruct of the common 'ijarah and specified ijarah. Thus, such evidence in fact goes against Kamal's own stance, because the Hanafi School was in agreement with other schools as this condition is a prohibitive clause to prevent issues of jahalah (ignorance) and gharar (ambiguity and/or uncertainty). Furthermore, these are among the fundamental Shariah prohibitions particularly in case of specified 'ijarah contract. Unlike IMAD where the subject matter is not subject to jahalah or gharar due to the fact that the features of the subject matter must be stipulated with its necessary traits, contracting parties are required to describe the quality of the object which includes both usufruct and counter value. Since counter value differs according to the quality of usufruct, it should be stipulated by way of making specifications. In addition, there are more justifications on the researchers' stance from the Majallat itself wherein several clauses (e.g., 538, $540,541,466)$ explicitly prove the authority of IMAD. For the sake of clarity, clause 540 states:

If it has been agreed upon by way of a bargaining to carry the objects to a certain place and the animal becomes fatigued and stops on the way, the owner of the animal shall be responsible to transfer such loads to another animal to carry them to destination they agreed upon at the outset (Basha 1302H: 85). 
In order to strengthen the support in favour of the researcher's arguments right from Murshid al-Hayran (1308H/1891) clauses it is mentioned that the consent of contracting parties, particularization of subject matter, knowledge of usufruct in a way that does not lead to any conflict shall be made compulsory to make IMAD authoritative. The discussion on the clause of Murshid al-Hayran is found very similar to what has been taken place in Majallah. Rather, clauses such as 580, 582, 598, and 616 can be put forward as justifications against Kamal's stance. Particularly, clause 598, which states:

If the musta'jir (hirer) hires a riding animal not for a particular purpose (e.g., to carry his luggage to a specific place), has the right to demand another animal (Basha 1891: 152).

The phrase 'riding an animal not for a particular purpose' means any animal stipulated by specifications. They disagreed with Abu Ghuddah (2007) and Nassar 's (2009) claims saying that Hanafi scholars did not permit the use of IMAD as a financing instrument. The Hanafi scholars considered usufruct as a non-valuable asset in its originality though, they have agreed on the permissibility of usufruct of 'ijarah contract notwithstanding the fact that it is a valueless asset according to general consensus of Hanafi scholars. This is regardless of whether it is a specified 'ijarah or usufruct in liability (i.e., forward 'ijarah) with the exception and khilafal-qiyas (opposite to analogical reasoning). This is in agreement with the findings of Mirah (2012: 8). However, all Hanafi scholars unanimously agreed upon the legitimacy of IMAD.

\section{Arguments Support the Authority of IMAD from Classical Literature}

Contemporary Muslim scholars like Qahaf (2010), al-Suwaylim (2009), Mirah (2012), and alShubayli (2012) and others have referred to the consensus on the legitimacy of IMAD in classical literature of Islamic jurisprudence. According to Qahaf, the four schools of Islamic Jurisprudence agreed on the permissibility of IMAD, and they did not look at the presence of the object as a condition at the time the contract is concluded, because it has the similar merits of bay salam in terms of liability based on the attachment of leasing to a specific object at a future date (Kahaf 1997: 41).

Mirah, while examining IMAD has referred to al-Suwaylim (2011) who made an analogous conclusion with Hanafi Scholars. They asserted that there is no deferment of leasing an object in this 'ijarah contract (i.e., IMAD); rather, there is a guarantee of the provision of changing the object in the event of its perishing. In accordance with Mirah, the ruling on the issuance of sukuk for the usufruct of objects stipulated in obligation depends mainly on the resolution of the fuqaha' with regard to ijarah of the usufruct of objects as stipulated in obligation; on which all four schools of Islamic jurisprudence (i.e., Hanafi, Maliki, Shafi'ie, \& Hanbali) are in agreement in general (Mirah 2012: 8).

Al-Shubayli (2012) has also made a similar statement which states that all scholars generally are of the agreement with the permissibility of 'ijarah as a financial product in Shariah no matter what if the subject matter is a particular item (specified) or described in obligation (IMAD). Attribution to illegitimacy of IMAD to the Hanafi scholars is inaccurate; rather, the views were expressed in their classical literature prove otherwise (i.e., its legitimacy). Not only that, alShubayli also criticized those attributed the impermissibility of IMAD to Hanafi School of Islamic jurisprudence (al-Shubayli 2012: 4).

From the evidences brought forward by these scholars, in the context of the abovementioned discussions, it is now evident that there were no disagreements among the classical scholars on the authority and permissibility of IMAD. Therefore, it is clear that all four prominent Islamic jurisprudential Schools (madhahib) have reached to an 'undisputed consensus', which should be taken as a strong evidence of its authority in Islamic commercial transaction, and therefore, the practice of IMAD in modern Islamic finance must be upheld. 
We may conclude from the above discussions that in previous literature all classical and contemporary Muslims jurists unanimously agreed upon the authority and permissibility of using IMAD as an Islamic financial instrument. Nonetheless, the contemporary Shariah scholars hold two different views with regard to those of classical scholars on whether the use of IMAD is valid in Islamic finance practice, and that there are disagreements among different schools of thought on its permissibility. Our investigations of the relevant literature show that a group of contemporary scholars who have claimed that Hanafi scholars disallowed the usage of IMAD is not based on fact or reality. Upon a thorough investigation of the issue we found that there were two assumptions behind their such claims:

1. It seems that these scholars were not fully aware of the holistic statements made by the Hanafi scholars on IMAD;

2. Perhaps, these scholars have somehow failed to undertake a rigorous research on all the relevant classical books or references of Hanafi school of Islamic jurisprudence.

Given these incorrect assumptions held by some scholars, we conclude that they have made a premature Islamic legal ruling on the validity and permissibility of the use of IMAD. Our research findings also nullify the scholar's claims as to why modern IFIs at their early stages did not practice IMAD as a stand-alone Islamic financial instrument. Perhaps, it so happened owing to their misconception about IMAD from the classical Shariah scholar's viewpoints. One of the major implications emerged from their misconceptions is that countries dominants or greatly influenced by Hanafi School of thought like Pakistan, Turkey, Lebanon, Bangladesh etc. did not recognize IMAD as an Islamically approved financing tool.

The present study, therefore recommends to reconsider the total acceptance of IMAD as an independent Shariah compliant financial product, and requests all concerned for the reconciliation and unification of contemporary Shariah scholars' mindsets on its renovations to enable it to accommodate to other modes of financing that are in practice in Islamic finance industry.

The study suggests the researchers in modern Islamic finance products to conduct further research on untapped areas of this topic to reach to a clear understanding about IMAD's structure, rules, parameters and its numerous versions. It is also a need of our time to undertake an extensive research the potential economic impact on IB's and IFI's practice of IMAD. This would help to act as a guide to develop innovative financial products and instruments commensurate with the encouraging economic impact. It further suggests that the research also needs to be carried out on the different possible risks are involved in IMAD in order to find Shariah-compliant means to minimize the risk factors to the lowest level. The study also suggests for conducting a rigorous research in order to help contribute to proposing financing real estate and other community building projects using IMAD.

\section{References}

Abu Ghuddah, A. S. 2007. Al-Tatbiqat al 'Amaliyyatu li al-Ijarat Mawsufat fi al-Dhimmah. Paper presented at the 28th Seminar of Islamic Economics on Dawr al-Mushtaqqat fi Ihdas alAzmat al-Maliyyah, The Kingdom of Bahrain.

Abu Moenes, R. N. 2013. Benefit Services in Islamic Banks. Amman: Radwan Publishing.

Ahmad Jawdat Basha, et al. 1302H. Majallat al-Ahkam al-Adliyyah. Vol. 1. Beirut: al-Matba'ah alAdabiyyah.

Ahmad, M. A. J. \& Hussain, L. 2013. Fiqh adaptation (takyif fiqhi) for the concept of a performance fee in takaful. ISRA International Journal of Islamic Finance. 5(2): 147. 
Ahmed, H. 2014. Islamic banking and Shari'ah compliance: a product development perspective. Journal of Islamic Finance. 3(2): 15-29.

Alrfoa, M. G. 2004. The Role of Leasing Financing Disclosure Described in University Education in Islamic Banks. Ph.D. Thesis. University of Islamic Sciences, The Hashemite Kingdom of Jordan.

Alzghadani, F. A. 2014. The Impact of Leasing Financing Parameters Described in the Disclaimer on the Benefit of Treatment In Jordanian Islamic Banks. Ph.D. Thesis. University of Islamic Sciences, Hashemite Kingdom of Jordan.

Amer, K. M., \& Radenarmad, N. 2012. Innovation in Islamic Banking: The Practical Application of Forward Ijarah, and Its Issues and Challenges. Paper presented at the 2nd ISRA Colloquium on "Islamic Finance in a Challenging Economy: Moving Forward". Sasana Kijang, Bank Negara Malaysia.

Asni, F., \& Sulong, J. 2018. Syariah analysis on hybrid contracts and its applications in Islamic housing financing in Malaysia. The Turkish Online Journal of Design, Art and Communication. September. Special issue: 1457-1462, doi: https://doi.org/10.7456/1080SSE/195.

Aswer, A. A., Jalil, A., \& Muhamed, N. A. 2019. A proposal of AMM (adapted mudarabah model) for Shariah compliant home financing in Malaysia. The Journal of Muamalat and Islamic Finance Research. 16(1): 82-96.

Basha, M. Q. 1891. Murshid al-Hayran ila Ma'rifat Ahwal al-Insan fi al-Mu'amalat al-Shar'iyyah. Misr: Al-Matba'ah al-Amiriyyah.

Bouchelaghem, S. 2015. Nahwa mi'yarin litaktifi uqudil maliyyat al-islamiyyah: aqdut ta'min alta'awuni anmudhajan(Towards a criterion to characterise Islamic financial contracts : Islamic insurance as a case study). ISRA International Arabic Journal of Islamic Finance. 6(1): 119-147. DOI: https://doi.org/10.12816/0019809.

al-Bujayrami, S. I. M. 1996. Tuhfat al-Habib 'ala Sharh al-Khatib. Beirut: Dar al-Kutub al-'Ilmiyyah. al-Buti, M. S. R. 2007. Al-ijarah al-Mawsufah fi al-Dhimmah. Paper presented at the AAOIFI Conference of Al-a`mal al-Mali wa al-Masrafi al-Islami, Bahrain. https://www.naseemalsham.com/subjects/view/46802. Retrieved: 25 January 2020.

Dewar, J., \& Hussain, M. 2017. Islamic Finance and Markets Law Review. London: Law Business Research.

Dieng, M. M. 2019. The applicability of ijarah al-mawsufah fi al-dhimmah in Malaysia. International Journal of Management and Applied Research. 6(4):194-205.

Doraisamy, B., Shanmugam, A., \& Raman, R. 2011. A study on consumers' preferences of Islamic banking products and services in Sungai Petani. Academic Research International. 1(3): 290.

Faddad, A. 2009. Al-Bay' 'ala al-Sifah li al-'Ayn al-Ghayibah wa ma yasbutu fi al-Dhimmah. Project Paper (56). Dubai: The Kingdom of Bahrayn.

Felix, R., \& Abubakar, L. 2019. Application of al-ijarah al-maushufah fi al-dhimmah for infrastructure project financing in Indonesia. Yuridika. 35(1): 129-152.

Ghafoor, S., Saba, I., \& Kouser, R. 2018. Sukuk issuance in Malaysia: lessons for Pakistan. Journal of Accounting and Finance in Emerging Economies. 4(2): 159-176.

Hallaq, W. B. 1996. Ifta' and ijtihad in Sunni legal theory: a developmental account. Islamic Legal Interpretation: Muftis and their Fatwas. Cambridge: Harvard University Press.

Haniyah, M. I., \& Barakah, I. M. 2019. Al-takyiful fiqhi fil ijtihadi wa dawrul ilmi fih. Majallah alJami'ah al-Islamiyyah li al-Dirasat al-Shar ïyyah wa al-Qanuniyyah. 27(2).

Hassan, R., Yousoff, A. \& Muneeza, A. 2012. Legal stains in the Malaysian Islamic banking practices of al-ijarah thumma al bai'(AITAB). World. 2(1): 95-100.

Ibn Jallab, A. Q. U. 378H. Al-Tafri'. Vol. 2. Beirut: Dar al-Gharb al-Islami.

Ibn Mazah, B. M. I. A. 2004. Al-Muhit al-Burhani al-Muhit fil Fiqhin Nu'mani. Beirut: Dar al-Kutub al-'Ilmiyyah.

Ibn Nujaym, Z. I. n.d. Al-Bahr al-Ra'iq Sharh Kanz al-Daqa'iq. Beirut: Dar al-Ma'rifah. 
Ibn Qudamah, M. 1997a. Al-Kafi. Vol. 3. Gizah: Hajr.

Ibn Qudamah, M. 1997b. Al-Mughni. 3rd ed. Vol. 8. Riyadh: Dar Alam al-Kutub.

Jalil, M. J. A., \& Rahman, Z. A. 2012. Sukuk investment: comparison of the profits obtained by using 'ijarah and musharakah mutanaqisah principles with long-term tenure. Qualitative Research in Financial Markets. 4(2/3): 206-227. doi:10.1108/17554171211252538.

Jinjiri Ringim, K. 2014. Perception of Nigerian Muslim account holders in conventional banks toward Islamic banking products. International Journal of Islamic and Middle Eastern Finance and Management. 7(3): 288-305. doi:10.1108/IMEFM-04-2013-0045.

Kahaf, M. 1997. Use of usufruct bonds in financing public utility. In. Ausaf Ahmad \& Tariqullah Khan (eds.). Islamic Financing Instruments for Public Sectors Resource Mobilization. Jeddah, Saudi Arabia: The Islamic Research and Training Institute. 1-52.

al-Kalbi, A. Q. M. 1425H. Al-Qawanin al-Fiqhiyyah fi Talkhis Mazhab al-Malikiyyah. Beirut: Dar alNafa'is.

Kalbi, N. H 2007. Fi fiqh al-Mu'amalah al-Maliyyah wa al-Masrafiyyah al-Mu'asarah: Qira'ah Jadidah. Damsyik: Dar al-Qalam.

al-Maqdisi, S. M. I. 2003. Kitab al-Furu'. Vol. 7. Beirut: Mu'assasat al-Risalah.

Masud, M. K., Messick, B., \& Powers, D. S. 1996. Muftis, fatwas, and Islamic legal interpretation. Islamic Legal Interpretation: Muftis and their Fatwas. pp. 3-32. Cambridge: Harvard University Press.

Mikail, S. A., \& Rani, M. S. M. 2016. Shariah contracts underpinning musharakah mutanaqișah financing: a conceptual analysis. ISRA International Journal of Islamic Finance. 8(1): 35.

al-Minhaji, S. M. I. 1996. Jawahirul 'Uqudi wa Mu'inul Qudati wal-Muwaqqi'ina wa al-Shuhud. Beirut: Darul Kutub al-'Ilmiyyah.

Mirah, H. b. H. b. M. A. 2012. Sukuk manafi' al-a'yan al-mawsufah fi al-dhimmah wa sukuk manafi' al-a'yan al-mu'ajjarah li man ba'aha ta'jiran muntahiyan bi al-tamlik. Paper presented at the 20th session of Majma' al-Fiqh al-Islami al-Duwali, King Adulaziz University, Jeddah.

Mohamad, S., Salah, O., Mokhtar, M., Alwi, S., \& Faigah, S. 2015. Enhancing cross border connectivity: venturing into Islamic finance as a new source of infrastructure financing. Journal of Emerging Economies and Islamic Research. 3(3): 1-14.

Monawer, A. T. M., \& Aziz, A. A. 2012. An Appraisal of al-Ijarah al-Mawsufah fi al-Dhimmah (Forward Ijarah) from Fiqh Perspective. Paper presented at the National Seminar on Contemporary Fiqh: Issues and Challenges, International Islamic University Malaysia (IIUM), Kuala Lumpur.

Muneeza, A., Mustapha, Z., Badeeu, F. N., \& Nafiz, A. R. 2019. Need to pioneer Islamic tourism in tourist resorts in Maldives. Journal of Islamic Marketing. Vol. ahead-of-print No. ahead-ofprint. https://doi.org/10.1108/JIMA-01-2019-0004.

Mutairi, M. H. 2011. Leasing property as described in Islamic finance tool in Saudi Arabia. M.A. Dissertation. Yarmouk University, Irbid, The Hashemite Kingdom of Jordan.

al-Nawawi, A. Z. Y. 2003. Rawdat al-Talibin (vol. 4). Riyadh: Dar Alam al-Kutub.

Nassar, A. M. M. 2009a. Dawabit al-ijarah al-mawsufah fi al-dhimmah wa tatbiqatuha fi tamwil alkhidamat fi al-mu'amalat al-maliyyah al-Islamiyah (the parameters of forward ijarah and its application in financing services in Islamic financial institutions). Paper presented at the 30th Seminar of Islamic Economics on "Dawr alMushtaqqat fi Ihdas al-Azmat al-Maliyyah (Role of Derivatives in Causing Financial Crisis)", The Kingdom of Bahrain.

Nassar, A. M. M. 2009b. Fiqhul ijaratil mawsufati fi dhimmati wa tatbiqatuha fil muntajatil maliyyatil islamiyyati litamwilil khadamat. Dirasah Iqtisadiyyah Islamiyyah. 16(2): 1-30.

Nizam, A. H. 596H/2000. Al-Fatawa al-Hindiyyah. Vol. 4. Beirut: Dar al-Kutub al-'Ilmiyyah.

Qahaf, M., \& Al-Jamal, M. M. 2013. Sukuk al-Ijarah al-Mawsufah fi al-Dhimmah. Paper presented at the 21th session of Majma' al-Fiqh al-Islami al-Duwali, King Adulzaiz University, K.S.A.

al-Qurahdaghi, A. M. U. 2008. Al-ijarah ala manafi' al-ashkhas: dirasah fiqhiyyah muqaranah fi alfiqh al-islami wa qanun al-amal (lease of personal benifits: a comparative study from fiqh 
perspective between Islamic jurisprudence and law of work). Paper presented at the 18th Conference, Paris.

Rafay, A., Sadiq, R., \& Ajmal, M. 2017. Uniform framework for sukuk al-ijarah: a proposed model for all madhahib. Journal of Islamic Accounting and Business Research. 8(4): 420-454.

al-Rafi'i, A. Q. 1323H. Taqrirat al-Rafi'i 'ala Radd al-Muhtar (Vol. 1). Riyadh: Dar `Alam al-Kutub. al-Ra'iyni, A. A. M. 2003. Mawahib al-Jalil li Sharhi Mukhtasar Khalil wa bi Hamishihi al-Taju wa aliklilu li Mukhtasari Khalil. In. Z. Umayrat (ed.). Beirut: Darul Kutub al-'Ilmiyyah.

Razak, D. A., Abu Samah, Z., \& A. W. H. 2016. Home buyers' perception on abandoned housing projects in Malaysia. International Journal of Business, Economics and Law. 9(1): 24-32.

al-Salem, F. H. 2009. Islamic financial product innovation. International Journal of Islamic and Middle Eastern Finance and Management. 2(3): 187-200. doi:10.1108/17538390910986326.

al-Samarqandi, A. 1984. Tuhfat al-Fuqaha. Vol. 2. Beirut: Dar al-Kutub al-Ilmiyyah.

Sana, A. S. A., \& Malahim, S. S. 2018. The effect of forward leasing determinants on financing the benefits of travel and transportation in Islamic banks: an empirical study in Jordan. Journal of Islamic Banking and Finance. 6(2): 1-12.

al-Sarakhsi, S. 2009. Al-Mabsut. Beirut: Dar al-Ma'rifah.

al-Shubayli, Y. I. A. 2012. Ahkam Isdar wa Tadawul Sukuk al-Ijarah al-Mawsufah fi al-Dhimmah wa Sukuk al-Ijarah Ma'a al-Wa'd bi al-Tamlik 'ala Man Ushturiyat Minh. Paper presented at the 20th session of Majma' al-Fiqh al-Islami al-Duwali King Adulaziz University, Jeddah.

al-Shirazi, A. I. I. 1995. al-Muhazzab. 1st ed. Vol. 2. Beirut: Dar al-Kutub al-'Ilmiyyah.

al-Suwaylim, S. 2009. Qadaya fil Iqtisadi wa al-Tamwil al-Islami. 1st ed. Riyadh: Dar al-Kunuzi Ishbiliya.

al-Suwaylim, S. 2010. Muntajat sukuk al-ijarah. Majallah ISRA al-Dawliyyah li al-Maliyyat alIslamiyyah. 1(1): 29-121.

Smolo, E., \& Hassan, M. K. 2011. The potentials of musharakah mutanaqisah for Islamic housing finance. International Journal of Islamic and Middle Eastern Finance and Management. 4(3): 237-258. doi:10.1108/17538391111166476.

al-Tanukhi, S. I. S. 240H. Al-Mudawwanah al-Kubra. Vol. 3. Beirut: Dar al-Kutub al-'llmiyyah.

al-Zuhayli, W. 2011. Al-Ijtihad fi zamanina hadha bayna al-nazariyyati wa al-tatbiq. Kyoto Bulletin of Islamic Area Studies. 4(1\&2): 1-9. 